\title{
The Development of Schoology-Based Blended Learning Model to Improve Student Motivation of National Training Center (PELATNAS) Athlete
}

\author{
Anung Priambodo*, Agus Hariyanto, Vega Candra Dinata \\ Pendidikan Olahraga \\ Universitas Negeri Surabaya \\ Surabaya, Indonesia \\ *anungpriambodo@unesa.ac.id
}

\begin{abstract}
Most student experience some difficulties in managing their study and training. The aim of this research is to develop schoology-based blended learning model to improve the motivation and learning outcomes of PELATNAS student athletes at Sport Sciences Faculty. This research used development research design. The research started with collecting data about the need for appropriate learning system for student athletes. The validation results from the experts stated that the schoology based blended learning model was good enough. Based on the results of the test and content validity ratio (CVR) analysis on 41 students of Sport Sciences Faculty, 88\% students perceived that schoology-based blended learning model is very good and $12 \%$ students felt good about this model. Moreover, analysis of motivation data show that as many as $\mathbf{1 7}$ students or $41.5 \%$ have a very high motivation category, while the remaining 24 or $58.5 \%$ of students have high motivation.
\end{abstract}

Keywords: athlete, blended learning, schoology, motivation

\section{INTRODUCTION}

Students are the next generation who must be prepared with various knowledge and skills that are in accordance with the needs of society and the progress of the times. In the era of education in the industrial revolution 4.0, the Indonesian nation was also faced with various changes in the world of education, especially with the emphasis on the use of the internet as a learning medium. In this era, technology has become a vital need for humans to fulfill various and daily tasks. Likewise in the world of education, the millennial generation is required to master technology in achieving educational effectiveness [1,2].

The existence of various sports competitions for students and students brings its own consequences for most students to compete in achieving sports achievements. To achieve optimal performance, it certainly cannot be separated from the training program that is carried out systematically and continuously. For student athletes, the demand for sports achievement and academic success brings the consequences of difficulty in managing time. In addition, research found that selfmanagement in the academic field between athletic students and non-athletes also different [3]. Non-athlete students have higher academic self-management than athletes so that student athletes in general will have difficulty achieving academic achievement if there is no suitable learning method.

Athletics is one of the compulsory courses for students in the Faculty of Sports Science, Universitas Negeri Surabaya. In general, the scope of athletic learning includes numbers: walk, run, jump and throw. For athletes who focusing on national training (PELATNAS), especially at the student level, lecture activities that should be followed regularly on campus will be hampered if training is being conducted at PELATNAS. They are required to follow the training program created by the trainers but on the other hand they are also expected to complete the lecture activities. To overcome this problem, it takes a learning system specifically designed to meet the needs of student athletes in achieving the success of their studies.

Blended learning is a format rapidly spreading in education worldwide [4]. Blended Learning is a combination of various approaches in learning. So that it can be said that Blended Learning is a learning method that combines two or more methods and approaches in learning to achieve the objectives of the learning process. The term Blended Learning according combines the best aspects of online learning, structured face-toface activities, and real world practice [1] Online learning systems, classroom training, and on-the-job experience have major drawbacks by themselves. The Blended Learning approach uses the others' weaknesses.

Blended Learning is a combination of online learning, faceto-face learning and experience in the real world. The combination of the above components can provide its own advantages in learning outcomes from students. [5]. Stated that blended learning integrates or blends learning programs in different formats to archives a common goal" which can be interpreted as Blended Learning to integrate or combine learning programs in different formats in achieving general goals. Meanwhile, blended learning as "the opportunity to integrate innovative and technological advances offered by online learning with the interaction and participation offered in the best of traditional learning. [4]. This system describes learning mixed as "representing this opportunity to integrate the innovative advancements and technologies offered by online learning with interaction and participation offered in the 
best of traditional learning". There are differences in active learning time in students with blended learning based on lectures and based on a problem-based approach. Students with problem-based blended learning are more active when they are learning compared to those who are based on lectures [6]. Three similarities or characteristics and definitions of Blended Learning: 1) a combination of learning models, 2) a combination of learning methods, 3) a combination of online learning and face-to-face learning.

Blended Learning is needed when the situation demands a combination or mixing various media methods, and techniques for achieving learning goals, for example when distance learning is not so needed, face-to-face learning is needed. This blended learning process is needed in students who need addition and combination in learning. Blended Learning has two main categories, namely: a) improved forms of face-toface activities (lectures), and hybrid learning that reduces faceto-face activities (lectures) but allowing students to study online.

Blended Learning has three components of learning which become one form of Blended Learning, namely online Learning, face to face learning and independent learning. Online learning is an educational material that is characterized by computerization. In Asynchronous Online Learning can send material at any time, while Synchronous Online Learning allows real time interaction between students and instructors online learning emphasizes that e-learning is done on the use of internet technology to send information that can improve knowledge and skills [7]. It can be concluded that online learning is a learning environment that uses internet technology, intranet, and web-based in the context of learning and learning among fellow students or by teaching anywhere and anytime. [1,4,8,9].

Face-to-face learning is a learning model that is still ongoing and is very often used in the learning process. Face-toface learning is a form of conventional learning model that brings teachers and students together in one class to study. The characteristics of face-to-face learning are: planned, placebased and social interaction. In face-to-face learning the teacher or student will use various methods in the learning process to make the learning process more active and interesting. Many other methods; lecture method, assignment, question and answer and demonstration. Independent learning is a system that allows people to learn to write independently from printed material, broadcast or pre-recorded material that has been prepared in advance. Thus, independent learning as a method can be defined as learning that positions students as responsible persons, control holders, decision makers or decision makers in learning and achieving learning achievement with or without the help of others.

Characteristics of independent learning systems according to the University of Maryland Distance Education Institute is freeing students not to have to study in one place at a time. A variety of materials (materials) including study guides and syllabi are provided and access to all members. Communication between students and instructors through a combination of several information technologies
This research is very urgent to do considering that national or international athletes have the status as a student. Become a student who is very good in sports performance (non academic) but also in completing learning in his school (academic).

The parameters for passing of courses in most educational institutions or universities are determined by the attendance, activeness, and test values carried out in writing (paper and pencil). For an athlete who is in training camps both at the regional level (Puslatda) and at the national level (Pelatnas), these conditions are difficult to fulfill. With such parameters, many student athletes become victims of the existing system so that some courses do not pass. This condition certainly decreases the motivation of students to learn because there are no facilities or media that can be used to study according to the demands of the existing Semester Lecture Plan (RPS).

Schoology is a site that combines social networks and learning management system (LMS) so users can engage in social interaction and learning as well as Edmodo and Moodle. A strong LMS must be able to do the following; a) using selfservice and self-guided services, b) collect and deliver learning content quickly, c) consolidate training initiatives on scalable web-based platforms, and d) supports portability and personalization of content standards and allows reuse of knowledge. Blended Learning based on Schoology is a learning that combines face-to-face learning and online learning using Schoology application outside of school hours. Students who used Blended Learning based on Schoology get more additional theories outside school hours individually, so that the face-to-face meetings to provide the theoretical material can be reduced and replaced with practicum to the student [10].

The features of schoology comprise courses. groups and resources. Courses which are facilities for creating subject classes, for example Mathematics, Physics, and so on. This course facility is also in Moodle. Groups, that is, facilities for creating groups. This facility is also on Moodle and on Facebook. Resources (Learning Resources).

In the Course menu, quizzes / questions (this feature is not owned by Facebook) that are of many types, namely multiple choice, right wrong, matching, short stuff, etc. can be made. Schoology provides more resources than what is provided by Edmodo. Schoology can also accommodate the type of question (question bank) that we will use in the Quiz. Another advantage of Schoology from Edmodo is the availability of Attendance facilities, which are used to check student attendance, as well as Analytic facilities (not supported by Moodle) to see all student activities on each course, assignments, discussions and other activities that we prepare for students. Through this analytic feature, any student activity is usually spent can be monitored when students are logged in.

\section{A. Motivation in Learning}

Various behavioural theories generally explain the two main bases of a person's behaviour, namely behaviour based on biological needs to maintain life and behaviour to get appreciation or avoid punishment as one of the most important components of learning, motivation is one of the most difficult aspects to measure [11]. The willingness of students to want to 
(relevant / important)

$\mathrm{N}=$ Number of all panellists

The CVR score for each item can range from 1 to -1 . A high score indicates high content validity for the item. An item that has a CVR $=0$ indicates that half the panel provides an item rating as an item that is relevant to the domain being measured [10]. The CVR value obtained in each item is then matched with the minimum value CVR table based on the significance test of p 50.05 presented by [14].

Minimum Value of CVR Based on Significance Test $\mathrm{p} \leq 0.05$

TABLE I. Minimum VALUE of CVR BASED ON SignificAnCE TeSt DATA

learning model was developed based on the results of Focus Group Discussion (FGD) with student athletes, athletic trainers and lecturers who are experts in the field of athletics. In addition, the design of this learning model was also compiled with various related research journals. The design of the learning model is prepared by considering the criteria: (1) the availability of lecture materials, (2) presented in the form of electronic material (e-book) and clear and interesting video tutorials (3) an attractive and motivating display for learning independently. After the design of the learning model is arranged, the blended learning based on schoology for athletics course has been validated by the learning experts.

\section{A. Subject of Research}

The subjects of this study were student athletes who joined in a concentration of sports training both in the region (PUSLATDA) and at the national level (PELATNAS). But in this study the subjects used as trials were students of the Sport Science department at Universitas Negeri Surabaya. The purpose of this trial is to know student responses in using schoology-based blended learning in athletic subjects

\section{B. Instruments}

- Test instruments used by expert validation and to know student responses to schoology-based blended learning learning are adapted from The Joint Committee on Standards for Educational Evaluation which includes four aspects, namely utility, feasibility, accuracy and propriety [13]

- The instrument for measuring motivation adapts from the Academic Intrinsic Motivation instrument

- In this study validation test uses content validity ratio (CVR). In the CVR approach, a number of respondents were asked to indicate whether a measurement item was important and in accordance with the objectives. Respondents' results are then used to calculate CVR for each item with an answer score of $0=$ irrelevant, $1=$ less relevant $2=$ relevant. Based on the results of the respondents, then calculated using the following formula.

$$
\mathrm{CVR}=(\mathrm{Ne}-\mathrm{N} / 2) /(\mathrm{N} / 2)
$$

Information:

CVR $=$ content validity ratio

$\mathrm{Ne}=$ Number of panellists who give assessment 2

\begin{tabular}{|l|l|}
\hline Number of Panelists & \multicolumn{1}{|c|}{ Minimum Value } \\
\hline 5 & 0,99 \\
\hline 6 & 0,99 \\
\hline 7 & 0,99 \\
\hline 8 & 0,78 \\
\hline 9 & 0,75 \\
\hline 10 & 0,62 \\
\hline 11 & 0,59 \\
\hline 12 & 0,56 \\
\hline 13 & 0,54 \\
\hline 14 & 0,51 \\
\hline 15 & 0,49 \\
\hline 20 & 0,42 \\
\hline 25 & 0,37 \\
\hline 30 & 0,33 \\
\hline 35 & 0,31 \\
\hline 40 & 0,29 \\
\hline
\end{tabular}

\section{RESULT}

The changing process of learning system from the traditional (face to face) to be more online system is not easy. That condition need support from the learning environment, peer support, and compatibility of the campus curriculum so that the transition of the learning system can be successful [15]. Based on the results of the validation of teach technology experts, athletic lecturers and developmental psychologists, it can be seen that the design of schoology-based blended learning skills in this athletic course has fulfilled all four aspects related to learning, namely utility, feasibility, accuracy and propriety. In the aspect of utility and politeness (propriety) has fulfilled the rules of learning, but in this aspect of online product feasibility, it still needs to be enriched with selfdeveloped video learning resources. Furthermore, in the aspect of accuracy, the selection of online learning needs to be harmonized with face-to-face learning and offline learning

The results of the student response analysis testing the use of schoology-based blended learning based on data resulted in $88 \%$ of students feeling that this schoology blended learning based learning was very good and $12 \%$ felt good. For CVR analysis in each aspect can be seen in table 2 below. 
TABLE II. CVR ANALYSIS OF STUDENTS RESPONSE

\begin{tabular}{|c|c|c|c|c|c|}
\hline \multirow{2}{*}{ Aspects } & \multirow{2}{*}{ item } & \multicolumn{3}{|c|}{ CVR Analysis } & \multirow{2}{*}{ Results } \\
\hline & & $\mathrm{Ne}$ & $N$ & $C V R$ & \\
\hline \multirow{7}{*}{ Utility } & 1 & 36 & 41 & 0.76 & Valid \\
\hline & 2 & 34 & 41 & 0.66 & Valid \\
\hline & 3 & 40 & 41 & 0.95 & Valid \\
\hline & 4 & 31 & 41 & 0.51 & Valid \\
\hline & 5 & 18 & 41 & -0.1 & Invalid \\
\hline & 6 & 36 & 41 & 0.76 & Valid \\
\hline & 7 & 39 & 41 & 0.9 & Valid \\
\hline \multirow{7}{*}{ Feasibility } & 1 & 34 & 41 & 0.66 & Valid \\
\hline & 2 & 33 & 41 & 0.61 & Valid \\
\hline & 3 & 33 & 41 & 0.61 & Valid \\
\hline & 4 & 33 & 41 & 0.61 & Valid \\
\hline & 5 & 38 & 41 & 0.85 & Valid \\
\hline & 6 & 32 & 41 & 0.56 & Valid \\
\hline & 7 & 30 & 41 & 0.46 & Valid \\
\hline \multirow{7}{*}{ Accuracy } & 1 & 37 & 41 & 0.8 & Valid \\
\hline & 2 & 24 & 41 & 0.17 & Invalid \\
\hline & 3 & 25 & 41 & 0.22 & Invalid \\
\hline & 4 & 23 & 41 & 0.12 & Invalid \\
\hline & 5 & 34 & 41 & 0.66 & Valid \\
\hline & 6 & 38 & 41 & 0.85 & Valid \\
\hline & 7 & 29 & 41 & 0.41 & Valid \\
\hline \multirow{5}{*}{ Propriety } & 1 & 36 & 41 & 0.76 & Valid \\
\hline & 2 & 36 & 41 & 0.76 & Valid \\
\hline & 3 & 38 & 41 & 0.85 & Valid \\
\hline & 4 & 37 & 41 & 0.8 & Valid \\
\hline & 5 & 36 & 41 & 0.76 & Valid \\
\hline
\end{tabular}

Based on the results of the analysis, it can be seen that in the aspect of accuracy, this schoology-based blended learning design still needs to be refined. Respondents felt that schoology-based online learning system had not been able to fully improve student motivation and learning outcomes. This is understandable because for practical lectures such as athletics, students still need face-to-face meetings to get feedback regarding the mastery of the movement that has been mastered. This is not enough to be discussed only with questions or uploading videos through an online system. In addition, the success of the implementation of this system is also very dependent on the independence or self-regulated learning of the student. For that reason, in the following year, improvements will be focused on the accuracy aspects of blended learning models to improve student motivation and learning outcomes.

Based on the analysis of motivation data can be seen that as many as 17 students or $41.5 \%$ have a very high motivation category, while the remaining 24 or $58.5 \%$ of students have high motivation. The use of blended learning in universities is increasingly needed in the era of the industrial revolution 4.0 because this system allows flexibility of time and place for students to study [16]. The latest research results show that the implementation of blended learning can develop three aspect of education, namely (1) supporting the existence of sustainable education, (2) forming a learning environment that is friendly and saves resources; and (3) eliminate the gap between women and men and create equality by eliminate the distance between people who live in the countryside and the city [17].

\section{CONCLUSION}

Based on the results of the research that has been obtained, it can be concluded that learning of schoology-based blended learning model in athletic subject is needed for National Training Center student athletes. Meanwhile, in the accuracy aspects of schoology-based blended learning design in athletic subjects still need some improvements. In conclusion, schoology-based blended learning model can increase learning motivation of National Training Center student athletes.

\section{ACKNOWLEDGEMENT}

Thank you to the Directorate of Research and community service that has provided funding for research. I also thank you for the athletes and coaches who have supported and the campus of Universitas Negeri Surabaya.

\section{REFERENCES}

[1] A. Buran and A. Evseeva, "Prospects of blended learning implementation at technical university," Procedia - Social and Behavioral Sciences, Elsevier, 206, pp. 177-182, 2015.

[2] M. Kaur, "Blended Learning - Its Challenges and Future," Procedia Social and Behavioral Sciences, 93, pp. 612-617, 2013.

[3] Cahyaningsih, "Perbedaan Manajemen Diri Akademik Pada Mahasiswa Atlet Dan Mahasiswa Non-Atlet Program Studi Pendidikan Jasmani Kesehatan Dan Rekreasi FIK UNY," Jurnal Bimbingan Konseling, 2016

[4] A.L. Nazarenko, "Blended Learning vs Traditional Learning: What Works? (A Case Study Research)," Procedia - Social and Behavioral Sciences. Elsevier, 200, pp. 77-82, 2015.

[5] S.C. Margaret Driscoll, "Advanced Web-Based Training Strategies : Unlocking Instructionality sound online learning," San Fransisco: Preiffer, 2005.

[6] Ö. Delialio, "Student Engagement in Blended Learning Environments with Lecture-Based and Problem-Based Instructional Approaches," 15, pp. 310-322, 2012.

[7] M. Ally, "Theory and Practice of Online Learning," Athabasca University, 2007.

[8] C.R. Curtis J. Bonk, "The Handbook of Blended Learning," USA: Preiffer, 2006.

[9] B. Güzer and H. Caner, "The Past, Present and Future of Blended Learning: An in Depth Analysis of Literature," Procedia - Social and Behavioral Sciences, 116, pp. 4596-4603, 2014.

[10] V.T. Irawan, E. Sutadji and Widiyanti, "Blended learning based on schoology: Effort of improvement learning outcome and practicum chance in vocational high school," Cogent Education, 4(1), 2017.

[11] C. Sansone and J.M. Harackiewicz, "Intrinsic and Extrinsic Motivation. The Search for Optimal Motivation and Performance," California: Academic Press, 2000.

[12] E. a Workman, and R.L. Williams, "The Effects of External Rewards on Intrinsic Motivation,” Journal of School Psychology, 18(2), pp. 141147, 2005.

[13] D.M. Handarini, "Pengembangan Model Pelatihan Keterampilan Sosial bagi Siswa Sekolah Menengah Umum Terpadu," unpublished Disertation, 2000. 
[14] C.H. Lawshe, "A Quantitative Approach to Content Validity," Personal Psychology, 28, pp. 563-575, 1975.

[15] M. Best and D. MacGregor, "Transitioning Design and Technology Education from physical classrooms to virtual spaces: implications for pre-service teacher education,” Int. J. Technol. Des. Educ., vol. 27(2), pp. 201-213, Jun 2017.

[16] R. Boelens, M. Voet, and B. De Wever, "The design of blended learning in response to student diversity in higher education: Instructors' views and use of differentiated instruction in blended learning," Comput. Educ., vol. 120, pp. 197-212, May 2018.

[17] C. Yao, "An investigation of adult learners' viewpoints to a blended learning environment in promoting sustainable development in China," J. Clean. Prod., vol. 220, pp. 134-143, May 2019. 